\title{
Sepsis urinaria, hidronefrosis severa y linfoma Burkitt
}

\author{
González Castro A, Suberviola B, Rodríguez-Borregan JC.
}

Servicio de Medicina Intensiva. Hospital Universitario Marqués de Valdecilla. Santander.

\section{Actas Urol Esp. 2008;32(3):367}

Daciente que ingresó en la UCI por una sepsis grave de origen urinario. Entre las pruebas diagnosticas realizadas se incluyó un TAC abdominal (Fig. 1), en el que se observó una gran masa de

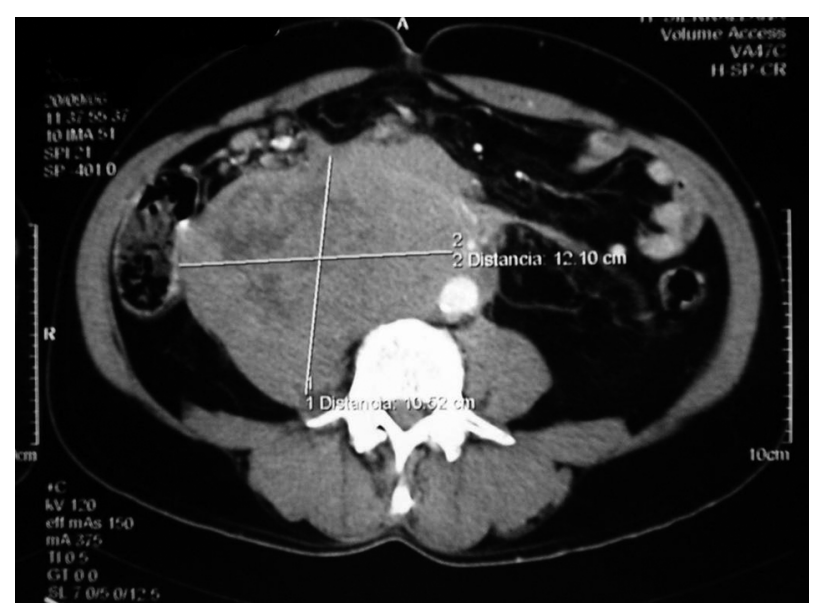

FIGURA 1
$10,52 \times 12,10 \mathrm{~cm}$. y aspecto heterogéneo con signos de necrosis en su interior que provocaba el desplazamiento y colapso de ambos uréteres con la consiguiente hidronefrosis de grado III. Se realizó una biopsia de la masa mediante una punción guiada por ecografía siendo diagnosticado de un linfoma tipo Burkitt. Recibió tratamiento con antibioterapia, corticoides y ciclofosfamida con una evolución satisfactoria.

Correspondencia autor: Dr. A. González Castro Servicio de Medicina Intensiva.

Hospital Universitario Marques Valdecilla Avda. Valdecilla s/n - 39008 Santander (Cantabria) Tel.: 942202520

E-mail autor: jandro120475@hotmail.com. Información artículo: Imágenes en Urología Trabajo recibido: octubre 2006

Trabajo aceptado: noviembre 2006 